\title{
Water Quality Modeling for Pollutant Carrying Capacity Assess- ment using Qual2Kw in Bedog River
}

\author{
Akhmad Darajati Setiawan, M. Widyastuti and M. Pramono Hadi \\ Received: Nov 2016/ Accepted: March 2018 \\ (C) 2018 Faculty of Geography UGM and The Indonesian Geographers Association
}

\begin{abstract}
Considering the abundance of potential pollutant sources along Bedog River, i.e. highly dense residential areas, agricultural lands, and industrial areas, this study aimed to quantitatively assess the Pollutant Load (PL) and Pollutant Carrying Capacity (PCC) of the river based on Chemical Oxygen Demand (COD) and Biological Oxygen Demand (BOD)parameters. The assessment employed a water quality modeling using Qual2Kw that provided not only the comprehensive values of PL and PCC but also the amount of PL that should be reduced to meet the PCC of every river segment. Water sampling and primary parameter measurement were conducted purposively in seven observation points, which included one point source and six non-point sources (river segments). River segments were determined according to the characteristics of land use and drainage system. Descriptive, graphic, and spatial analyses on water quality modeling show that the COD and BOD of Bedog River $(2.24 \mathrm{~km})$ indicates a small presence of PL compared to the river's PCC. The PCC allows additional pollutant loads of $566.95 \mathrm{~kg} / \mathrm{day}$ or 0.024 ton/hour BOD and 22,965.12 kg/ day or 0.96 ton/hour COD. However, a high BOD in segments 3, 5, and 6 and a high COD in segment 5 imply the needs for PL reduction.
\end{abstract}

\begin{abstract}
Keywords: Pollutant Load (PL), Pollutant Carrying Capacity (PCC), Bedog River, Qual2Kw
Abstrak Sungai Bedog merupakan salah satu sungai yang melalui area padat permukiman, peternakan, dan aktivitas pertanian, serta industri rumah tangga. Penelitian ini bertujuan untuk mengetahui nilai beban pencemar (BP) dan nilai daya tampung beban pencemar (DT) untuk parameter COD dan BOD. Berdasarkan paremeter ini dapat diketahui juga nilai beban pencemar yang harus dikurangi agar sesuai dengan nilai daya tampung beban pencemar per penggal sungai. Pemodelan kualitas air dengan Qual2Kw digunakan untuk pendapatkan nilai beban pencemar dan nilai daya tampung beban pencemar yang komprehensif. Pengambilan sampel air dan pengukuran parameternya dilakukan secara purposive pada tujuh titik pengamatan sebagai sumber titik (point source) dan pada enam penggal sebagai sumber area (non-point source). Penentuan penggal-penggal ini didasarkan pada karakteristik penggunaan lahan dan sistem drainase di sekitarnya. Hasil penelitian menunjukan bahwa penggal Sungai Bedog di daerah penelitian $( \pm 2.24 \mathrm{~km})$ masih mampu menampung beban pencemar. Sungai ini masih mampu menampung beban pencemar BOD sebesar $566.95 \mathrm{~kg} / \mathrm{hari}$ dan beban pencemar COD sebesar 22.965,12 kg/hari. Penggal sungai yang harus dikurangi beban pencemarnya adalah pada penggal 3, penggal 5, dan penggal 6 untuk parameter BOD. Pengurangan beban COD hanya pada penggal 5.
\end{abstract}

Kata kunci: Nilai Beban Pencemar (BP), Nilai Daya Tampung Beban Pencemar(DT), Sungai Bedog, Qual2Kw.

\section{Introduction}

Water is one of the basic resourcesin human life, therefore, meeting its demand means providing not only available quantity but also uncontaminated quality [Sudarmadji et al., 2011]. Surface water is easily polluted, leading to water quality deterioration and low abstraction. Part of water resource management, particularly of surface water, is minimizing human impacts on water quality. Therefore, assessing the Pollutant Carrying Capacity (PCC) of related surface water becomes necessary.

PCC represents the capacity of water source to 'allow' the presence of certain Pollutant Load (PL) from various sources without contaminating its quality (Decree of the Indonesian Minister of Environment No. 1/2010). PCC cannot be assessed directly because it

Akhmad Darajati Setiawan, M. Widyastuti, M. Pramono Hadi Departmen Geography, Faculty of Geography, Universitas Gadjah Mada, Indonesia.

Corresponding email: akhmad.darajati@mail.ugm.ac.id / akhmaddarajati@gmail.com involves a complex interrelationship between its factors. In order to simplify it, PL is assessed using Qual2Kw method, i.e. a numerical modeling of river water quality [Abdi, 2011]. Qual2Kw models are used as river water quality management tools because they emulate the response of water bodies to pollution. Accordingly, they are referred to as the guidelines for policies, regulations, and permits on disposing pollutant into river channels [Oliveira et al., 2012], and for the formulation of water quality management strategies [Kannel et al., 2007].

Qual2Kw is the renewal of Qual2E and Qual2K. Qual2E is a modeling method developed by Brown and Barnwell [1987] that simplified the condition of water quality along the rivers especially based on the level of Dissolved Oxygen (DO) and Biological Oxygen Demand (BOD) [Fatmawati et al., 2012]. Park and Lee [2002] developed Qual2E into Qual2K with additional tools, such as extensive computation structures, more representative water quality parameters (i.e. BOD, DO, and denitrification), and an increase in the quantities of confluence, river segments, and measurement elements. 
The latest development, Qual2Kw, is equipped with the ability to simulate various water quality parameters, including Electrical Conductivity (EC), temperature, DO, CBODslow, CBODfast, Phosphate, Nitrogen, phytoplankton, detritus, pathogen, alkalinity, $\mathrm{pH}$, etc. [Pelletier et al., 2006].

Bedog River flows through a highly dense residential area, agricultural land, and industrial area. Intensive development and construction along the river, which potentially lead to negative impacts on the environment [Sudarmadji and Widyastuti, 2014], have raised a concern on river water quality. Hence, this study specifically chose Bedog River and used its surrounding land utilization as an approach to represent the pollution emission factor required in assessing the PL potential of domestic, agricultural, and industrial activities in every village in the study area through weighted average calculation.Accordingly, this study developed a water quality modeling based on two key parameters of pollutant loads, i.e. BOD and COD.

The water quality modeling aimed to: 1) quantitatively measure the Pollutant Load in every surveyed segment of Bedog River, as indicated by Biological Oxygen Demand (PLBOD) and Chemical Oxygen Demand (PLCOD); 2) assess the Pollutant Carrying Capacity of every river segment in terms of Biological Oxygen Demand (PCCBOD) and Chemical Oxygen Demand (PCCCOD); and 3) quantify the amount of PLBOD and PLCOD that should be reduced to meet the PCCBOD and PCCCOD of Bedog River.

The water quality modeling aimed to: 1) quantitatively measure the Pollutant Load in every surveyed segment of Bedog River, as indicated by Biological Oxygen Demand (PLBOD) and Chemical Oxygen Demand (PLCOD); 2) assess the Pollutant
Carrying Capacity of every river segmen tin terms of Biological Oxygen Demand (PCCBOD) and Chemical Oxygen Demand (PCCCOD); and 3) quantify the amount of PLBOD and PLCOD that should be reduced to meet the PCCBOD and PCCCOD of Bedog River.

\section{The Methods}

Bedog River is part of Progo Watershed that according to the Decree of the Indonesian Minister of Forestry No. SK.328/Menhut-II/2009 is categorized as critical. In addition, based on the Preliminary Draft of Regional Development Plan (RKPD) of Yogyakarta in 2015 [BAPPEDA DIY, 2015], Bedog is categorized as a highly polluted river. Population growth and developing urban activities in Bedog Sub-Watershed increase the potential for introducing pollution into the river.

Water sampling locations were chosen purposively by considering the distance between seven observation points and land utilizations that commonly used ditches to dispose their waste into the river and presumably degraded the water quality of Bedog River. The ditch networks, thereby, became the most consideration in water sampling and the extent of the study area. The flow direction map of ditch networks and irrigation channels as well as the distribution of water sampling locations are presented in Figure 1.

The following points list the data acquired during the study.

1) River Discharge, acquired through direct measurement using slope area method. The formula is as follows [Soewarno, 2014]:

$$
V=\frac{k^{\frac{2}{2}} \cdot s^{\frac{1}{2}}}{n} \mathrm{and} Q=\frac{1}{n} \cdot A \cdot R^{\frac{2}{2}} \cdot S^{\frac{1}{2}}
$$

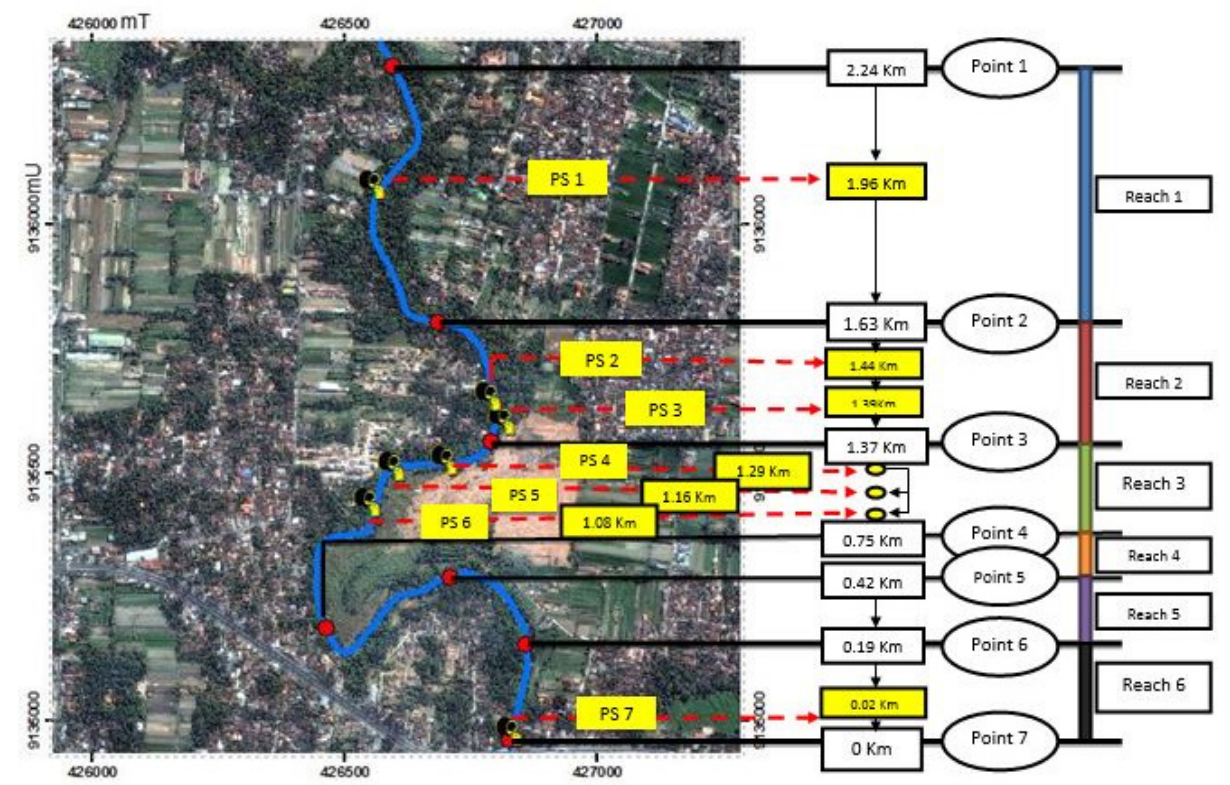

Figure 1. The flow direction of ditch networks and irrigation channels, river segments, and water sampling locations ( $\mathrm{PS}=$ Point Source; Point = water sampling point) 
where:

$\mathrm{V}=\operatorname{river} \operatorname{velocity}(\mathrm{m} / \mathrm{s})$,

$\mathrm{Q}=\operatorname{discharge}(\mathrm{m} 3 / \mathrm{s})$,

$\mathrm{n}=$ Manning's roughness coefficient,

$\mathrm{A}=$ cross-sectional area $(\mathrm{m} 2)$,

$\mathrm{R}=$ hydraulic radius $(\mathrm{m})$; obtained from

$\mathrm{R}=\mathrm{A} / \mathrm{P}(\mathrm{P}=$ wet perimeter, meter $)$, and

$\mathrm{S}=$ water-surface slope.

2) Water Quality, acquired from seven water samples of river bodies and seven water samples of point pollutant sources. The water sampling location on Bedog River was based on the surrounding land use and the travel time of river flows. The travel time was assessed using the following formula [Achmad, 2012].

$$
t c=\frac{2}{60 \times V}
$$

where:

tc = time of concentration (minute),

$\mathrm{L}=$ stream length (meter), and

$\mathrm{V}=$ rver velocity $(\mathrm{m} / \mathrm{s})$

3) Slope of riverbed, measured using abney level.

4) Cross section measures, obtained from crosssectional profiling on Bedog River.

5) Measures of cloud cover and shade, obtained from direct measurement with the help of quadrant graph paper and direct observation.

6) Secondary data of temperature, dew point, and wind speed, obtained from related climate institutions

7) The size of agricultural area, number of livestock, and population size, assumed as the sources of pollution. Their pollutant loads were measured using the following formula [Iskandar, 2007, modified by Abdi, 2011]:

a) Agricultural pollutant load $\left(\mathrm{PL}_{\text {Agriculture }}\right)$

$\mathrm{PL}_{\text {Agriculture }}($ ton $/$ hour $)=(($ Emission factor $\times \mathrm{L} \times \mathrm{M}) /$ $\mathrm{dM}) / 1,000$

where:

$\mathrm{L}=$ size of agricultural land,

$\mathrm{M}=$ number of cropping seasons, and

$\mathrm{dM}=$ duration of cropping season (hour).

b) Livestock pollutant load $\left(\mathrm{PL}_{\text {Livestock }}\right)$

$\mathrm{PL}_{\text {Livestock }}($ ton/hour $)=($ Number of livestock $x$ Emission factor)/ 1,000,000)/24

c) Domestic pollutant load $\left(\mathrm{PL}_{\text {Domestic }}\right)$

$\mathrm{PL}_{\text {Domestic }}($ ton $/$ hour $)=($ Population size

$x$ Emission factor $x$ CER $x$ alpha $(\alpha)) /$

$1,000,000 / 24$

where:

$\alpha=$ river segment coefficient

CER = City Equivalent Ratio
Pollution emission factor was calculated using the weighted average of agricultural and domestic land utilizations in the study area [Soewarno, 2014].

$$
\bar{X} w \frac{\sum_{i=l}^{n} W i x X i}{\sum_{i=1}^{n} W i}
$$

where:

$$
\begin{aligned}
\bar{X} w & =\text { weighted average, } \\
X i & =\text { the } \mathrm{i} \text {-th data, } \\
W i & =\text { the } \mathrm{i} \text {-th weight, and } \\
\mathrm{n} & =\text { number of data. }
\end{aligned}
$$

\section{Qual2Kw Modeling}

\section{Data Input}

The modeling input consisted of river segment borders, hydrological data and river morphometry, climatological data, water quality data, and pollutant potentials.

\section{Model Running}

Model running was performed after data entry. The Qual2Kw program was executed through qual2kw.exe.

\section{Calibration and Reliability Test}

The results of Qual2Kw model running were calibrated using trial and error, i.e. adding or reducing the pollutant load to produce the closest estimated value to the observed pollutant load. Afterwards, the results of trial and error were validated using chi-square $(\chi 2)$ formula:

$$
\chi^{2}=\sum_{n=1}^{n} \frac{(\text { Observed vaitue }- \text { Estimated vaitue })^{2}}{\text { Estimated vaitue }}
$$

where:

$\mathrm{n}=$ number of samples

$\mathrm{r}=$ the $\mathrm{n}$-th sample

The estimated $\chi^{2}$ was compared to the $\chi^{2}$ from the table with 0.95 or $95 \%$ confidence level $(\alpha)$. If the $\chi^{2}$ estimate $<\chi^{2}$ table, then the results of Qual2Kw modeling are viable. On the contrary, if the $\chi 2$ estimate $>x^{2}$ table, then the results are not viable [Soewarno, 2 014].

Following the validity test was a reliability test that determined the accuracy of the measurement process and the dependability of Qual2Kw models [Meeker and Escobar, 1998]. The formula for the reliability test is as follows.

A. rB method

$r B=\frac{\left(R m_{i}-R O\right)}{S 0}$ and $F=\frac{S m^{2}}{S O^{2}}$ 
where:

$F \quad=$ ratio of estimated (modeled) to observed variation,

$\mathrm{Rm}=$ mean estimated value,

Ro = mean observed value,

So = standard deviation of observed values, and

$\mathrm{Sm}=$ standard deviation of estimated values.

If $-0.5<r B<0.5$ and $0.5<F<1.5$, then the model is reliable. However, if $\mathrm{rB}<-0.5$ or $r B>0.5$ and $\mathrm{F}<0.5$ or $\mathrm{F}>1.5$, then the model is not reliable [Montgomerry, 1997].

B. MRE method

$$
R E=\frac{\text { (Observed value }- \text { Estimated value) }}{\text { Observed value }} \times 100 \%
$$

where:

$R E \quad=$ Relative Error (\%),

$M R E \quad=$ Mean Relative Error (\%),

$n \quad=$ number of samples, and

$r \quad=$ the $n$-th sample.

The model is reliable when $\mathrm{MRE}<10 \%$ but not reliable when MRE > 10\% [Badrus and Syafrudin, 2007].

\section{Data Analysis}

The results from the Qual2Kw modeling were analyzed graphically, descriptively, and spatially in order to facilitate a thorough comprehension. The difference between the estimated PCC and PL is the required amount of $\mathrm{PL}$ reduction

\section{Result and Discussion}

This study, which was conducted in a small part of Bedog River, produced satisfactory results that correspond to a study conducted by Oliveira et al. [2012], i.e. Qual2Kw is applicable for a short river segment and a small watershed, as part of aquatic environment evaluation.

\section{River Discharge}

River discharge was measured directly at the locations of water sampling based on the requirement of Qual2Kw modeling. The variation in river discharge was due to different river width, water depth, Manning's roughness coefficient, and cross section's slope in every sampling location. It increased from $6.85 \mathrm{~m} 3 / \mathrm{s}$ at point 1 to $7.72 \mathrm{~m} 3 / \mathrm{s}$ at point 2 and continuously fluctuated until it reached point 4 . Afterwards, it increased to 8.09 $\mathrm{m} 3 / \mathrm{s}$ at point 6 and $8.25 \mathrm{~m} 3 / \mathrm{s}$ at point 7 . The highest river discharge found at point 7 was strongly influenced by stream inflows and the measures of cross sections at this point.

The discharge of Bedog River in rainy seasons is relatively high. The low discharge is caused by the wide and shallow river channel, while the high discharge is caused by the relatively narrow and deep river channel. Moreover, riverbed material, river channel homogeneity, vegetation and building factors, as well as the meandering level considered in the calculation of Manning's coefficient also influence the results of the discharge measurement. The flow velocity and the discharge of Bedog River are presented in Table 1.

\section{River Water Quality}

BOD in every water sample was below (not exceeding) the Water Quality Standards for Class II (Figure 2). The variation of BOD was due to the concentration of biodegradable organic waste, e.g. proteins, sugars, and carbohydrates as well as Nitrogen in its free form (i.e. NH4), which is not measurable in COD [Wardhana, 2011].

COD in every water sample met the criteria for Class II in Water Quality Standards (Figure 3). It was higher than BOD because COD laboratory analysis involved more stabilized compounds in biological reaction, whichwere possibly oxidized during the analysis. The level of observed COD varied according to the concentration of organic waste, synthetic fiber, cellulose, non-biodegradable waste (NO2-, NO3, FE2+, S2-, Mn3+), aromatic hydrocarbon, and hydrocarbon chains [Wardhana, 2001].

\section{Point Source Pollution (PSP)}

Point source pollution is any source of pollution that discharges pollutants into the river bodies through sewage pipes, ditches, etc. The water samples of Bedog River were located at seven point sources of pollution that potentially introduced contaminated inflows into the river. The BOD and COD concentrations of these samples are presented in Table 2.

Laboratory analysis revealed that, compared to rice field and aquaculture, domestic activities and tofu industries were the point sources of pollution that contributed to the presence of high PL in Bedog River.

\section{Non-Point Source Pollution (NPSP)}

In order to quantify the PL potential of activities taking place along the river, the pollution emission factor was estimated using land utilization. In this study, NPSP represented the PL of three land utilizations that discharged pollutant into every river segment. The results of NPSP analysis are presented in Table 3.

The numerical order of NPSP represents the number of river segment. For instance, NPSP 1 denotes the NPSP of segment 1 . The highest BOD and COD were found in segment 2 , i.e. 0.013 ton/hour and 0.0075 ton/hour, respectively, which were in line with the highly contaminated inflows coming from residential area, rice field, and livestock farming in segment 2 .

\section{Pollutant Load (PL)}

The estimated $\mathrm{BOD}$ and $\mathrm{COD}$, resulted from Qual2Kw modeling, went through repetitive simulations, or known as trial and error, to produce a combination that resembled or was equivalent to the 
observed BOD and COD (i.e. the results of laboratory analysis).The best models of BOD and COD are presented in Figure 4 and Figure 5.

Afterwards, the best simulation was analyzed with chi-square and reliability tests. The valid and dependable model was, then, utilized to estimate the level of BOD and COD, which represented the PL of every river segment. The concentration of PLBOD and PLCOD are represented in Table 4 and table 5, respectively.

PLBOD of Bedog River was 2,007.96 kg/ day. Negative PLBOD in segment 1, 2, and 4 representedmorphometric factors that led to the occurrence of self-purification in segment 1 . Negative PLBODin segment 1 and 2 also occurred due to the presence of stream inflows that potentially discharged better water quality and, subsequently, diluted the concentrations of pollutant load. Meanwhile, high BOD in segment 6 was caused bypollutant inflows from NPSP 6 and PSP 7, i.e. sewage pipes of tofu industries, which had the highest pollutant load among the other sources of pollution (324.24 mg/L). Consequently, segment 6 had the highest PLBO Damong the other segments.

PLCOD of Bedog River was 3,310.84 kg/day. The negative levels of PLCOD in segment 2 and

Table 1. The Flow Velocity and Discharge of Bedog River

\begin{tabular}{cll}
\hline Points & Velocity $(\mathrm{m} / \mathrm{s})$ & Discharge $(\mathrm{m} 3 / \mathrm{s})$ \\
\hline 1 & 1.45 & 6.85 \\
2 & 1.28 & 7.72 \\
3 & 1.81 & 7.55 \\
4 & 1.55 & 7.49 \\
5 & 1.21 & 7.73 \\
6 & 1.15 & 8.09 \\
7 & 0.9 & 8.25 \\
\hline
\end{tabular}

Source: Direct Measurement, 2015

Table 2. BOD and COD at Seven Point Sources of Pollution

\begin{tabular}{rrrl}
\hline PSP & $\begin{array}{r}\text { BOD } \\
(\mathrm{mg} / \mathrm{l})\end{array}$ & $\begin{array}{r}\text { COD } \\
(\mathrm{mg} / \mathrm{l})\end{array}$ & Sources of Pollution \\
\hline 1 & 4.10 & 4.63 & Aquaculture \\
2 & 19.41 & 36.36 & Domestic activities \\
3 & 1.31 & 0.99 & Rice field \\
4 & 55.77 & 223.80 & Tofu industry and \\
& & & domestic activities \\
5 & 1.31 & 0.49 & Rice field \\
6 & 0.58 & 0.74 & Rice field \\
7 & 324.24 & 1942.13 & Tofu industry \\
\hline
\end{tabular}

Source: LaboratoryAnalysis, 2015
3 were caused by self-purification or PL dilution, resulted from stream inflows with good water quality. The highest concentration found in segment 5 was the result of pollutant inflows from NPSP 5. This segment was morphometrically characterized with the narrowest river channel among the other segments, low meandering, and short distance, all of which prevented an optimum self-purification. Another cause of this level of concentration was the surrounding land use, viz. plantation, dry agricultural land, screen-printing industry, and sawmill industry that potentially emitted non-biodegradable waste materials like $\mathrm{NO} 2$ or NO3, synthetic fiber, and cellulose, which were measurable in COD analysis.

\section{Pollutant Carrying Capacity (PCC)}

Trial and error on BOD and COD simulation was performed until the estimated BOD and COD were just below the Water Quality Standards (Figure 6 and Figure 7). This process quantified the discharge and the BOD and COD concentrations that were used in the calculation of Pollutant Carrying Capacity (PCP). The PCCBOD and PCCCOD of every segment are presented in Table 6 and Table 7.

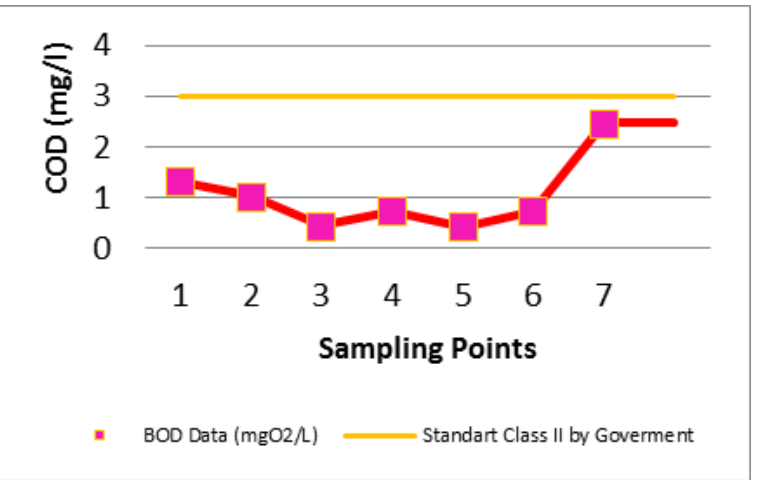

Figure 2. Observed BOD Concentration (Laboratory Analysis)

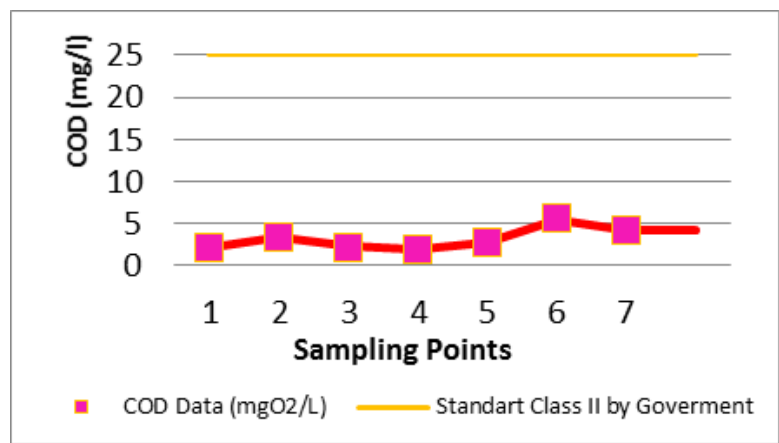

Figure 3. Observed COD Concentration (Laboratory Analysis) 


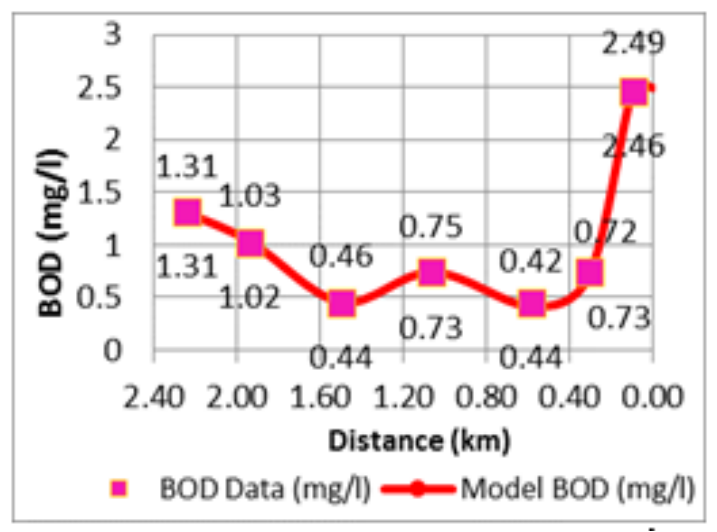

Figure 4. BOD Simulation using Qual2Kw Modeling

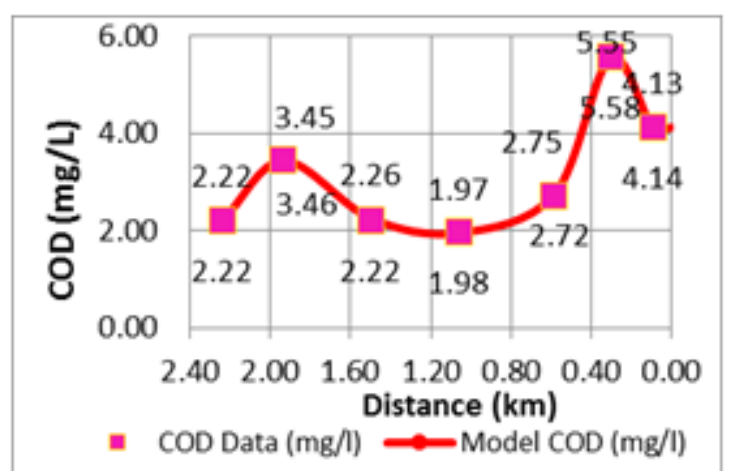

Figure 5. COD Simulation using Qual2Kw Modeling

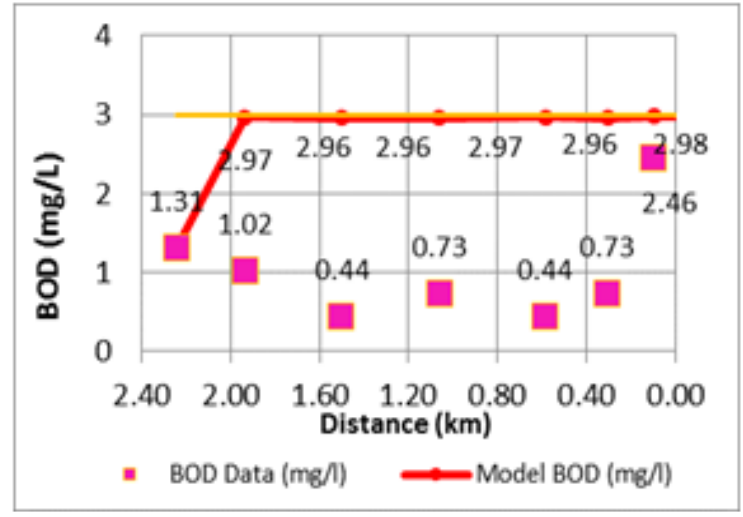

Figure 6. Estimated PCCBOD from Qual2Kw Modeling

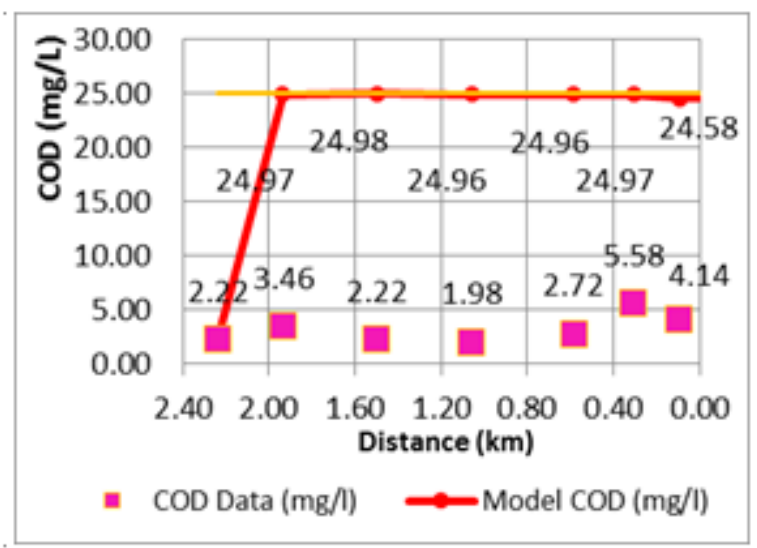

Figure 7. Estimated PCCCOD from Qual2Kw Modeling
Table 3. NPSP Analysis Result

\begin{tabular}{lrr}
\hline NPSP & BOD (ton/hour) & COD (ton/hour) \\
\hline NPSP 1 & 0.0056 & 0.00049 \\
NPSP 2 & 0.013 & 0.0075 \\
NPSP 3 & 0.0010 & 0.00080 \\
NPSP 4 & 0.00030 & 0 \\
NPSP 5 & 0.00016 & 0 \\
NPSP 6 & 0.0069 & 0.0013 \\
\hline \multicolumn{2}{c}{ Source: Laboratory Analysis, 2015 }
\end{tabular}

Table 5. Estimated PLCOD of Bedog River

\begin{tabular}{lrr}
\hline Segments & PLCOD (kg/day) & PLCOD (ton/hour) \\
\hline Segment 1 & $1,036.88$ & 0.043203 \\
Segment 2 & -604.60 & -0.02519 \\
Segment 3 & -49.90 & -0.0021 \\
Segment 4 & 907.20 & 0.083 \\
Segment 5 & $3,110.40$ & 0.13 \\
Segment 6 & $-1,098.14$ & -0.045 \\
TOTAL & $3,310.84$ & 0.138 \\
\hline
\end{tabular}

Source: Data Analysis, 2015

Table 6. Estimated PCCBOD of Bedog River

\begin{tabular}{lrr}
\hline Segments & PCCBOD (kg/day) & $\begin{array}{r}\text { PCCBOD (ton/ } \\
\text { hour) }\end{array}$ \\
\hline Segment 1 & $1,252.85$ & 0.052202 \\
Segment 2 & 250.60 & 0.010442 \\
Segment 3 & 267.91 & 0.0111632 \\
Segment 4 & 267.84 & 0.011 \\
Segment 5 & 250.56 & 0.010 \\
Segment 6 & 285.15 & 0.011881 \\
TOTAL & $2,574.92$ & 0.107 \\
Source: Data Analysis, 2015 &
\end{tabular}

Source: Data Analysis, 2015

Table 7. Estimated PCCCOD of Bedog River

\begin{tabular}{lrr}
\hline Segments & PCCBOD (kg/day) & $\begin{array}{r}\text { PCCBOD (ton/ } \\
\text { hour) }\end{array}$ \\
\hline Segment 1 & $15,725.23$ & 0.65522 \\
Segment 2 & $2,194.91$ & 0.09145 \\
Segment 3 & $2,203.85$ & 0.09183 \\
Segment 4 & $2,203.20$ & 0.092 \\
Segment 5 & $2,203.20$ & 0.092 \\
Segment 6 & $1,728.22$ & 0.072009 \\
TOTAL & $26,258.60$ & 1.09411 \\
\hline
\end{tabular}

Source: Data Analysis, 2015 


\section{Pollutant Load Reduction}

The difference between PL and PCC shows the amount of pollutant load that should be reduced or that can be 'carried' by every segment of Bedog River. Either of these data provides a reference for issuing permits or regulations of waste management. The difference between PL and PCC is presented in Table 8 and Table 9.

The difference between PLBOD and PCCBOD insegment 1 was $1,321.90 \mathrm{~kg} /$ day, which indicated the capacity of this segment to still 'carry' such amount of PLBOD. Similar capacity was found in segment 2 and 4. Because segment 1 had the widest difference, this segment had the highest PCCBOD among the other segments. On the contrary, the differences between PLBOD and PCCBOD in segment 3, 5, and 6 were negative, which indicated the need for PL reduction. The quantities of PLBODthat should be reduced in segment 3, 5, and 6 were $17.70 \mathrm{~kg} /$ day, $95.04 \mathrm{~kg} /$ day, and $1,748.06 \mathrm{~kg} /$ day, respectively.

Based on the difference between PLCOD and PCCCOD, almost all of the river segments, namely segment $1,2,3,4$, and 6 , were able to carry more PLCOD. Segment 6 could carry more $2,833.94 \mathrm{~kg} /$ day pollutant load, which was the highest among the other segments. Meanwhile, segment 5 was the only segment that required PLCOD reduction as many as $907.2 \mathrm{~kg} /$ day.

The results of this study are fundamental to reduce the exceeding pollutant load in every segment in order to help the government formulating policies on waste disposal through sewage pipes and into river bodies, particularly on river segments that no longer have the capacity to carry more pollutant load. Moreover, land use evaluation needs to be considered in minimizing the polluting potential of land use along Bedog River.

This study was conducted on limited data availability. Therefore, future research on Qual2Kw modeling for pollutant carrying capacity has to be performed with a time series of more thorough and reliable climatological and hydrological data as well as that of water quality and source of pollution. With this level of data availability, researchers and related stakeholders can perform the modeling efficiently with more inclusive results.

\section{Conclusion}

The PCC (Pollutant Carrying Capacity) allows additional pollutant loads of $566.95 \mathrm{~kg} /$ day or $0.024 \mathrm{ton} /$ hour BOD and 22,965.12 kg/day or 0.96 ton/hour COD. However, a high BOD in segments 3, 5, and 6 and a high COD in segment 5 imply the needs for PL reduction. Water quality modeling show that the COD and BOD of Bedog River $(2.24 \mathrm{~km})$ indicates a small presence of PL (Pollutant Load) compared to the river's PCC. As a conclusion, the PLCOD and PLBOD of parts of Bedog River that flowed through the study area did not exceed their PCCCOD and PCCBOD. For further research, this method can be developed in longer and complex river pollutant loads with multiple water sampling for data accuracy. Application in the karst area can also be developed in the future study.

\section{Acknowledgement}

This article is a part of research of the author and co-author at Faculty of Geography, Universitas Gadjah Mada, Indonesia. The author wishes to extend his perfound gratitude especially to Faculty of Geography, Universitas Gadjah Mada. The great gratitude goes to all colleague who have already help on conducting the research both in field and studio.

\section{References}

Abdi, Z. (2011). Kajian Daya Tampung Beban Pencemaran Sungai Batanghari Pada Penggal Gasiang - Sungai Langkok Provinsi Sumatera Barat. Tesis. Yogyakarta : Program Pascasarjana Fakultas Geografi UGM.(in bahasa Indonesia)

Achmad, M. (2012). Hidrologi Teknik. Makassar : Universitas Hasanudin.(in Bahasa Indonesia)

Badrus, Z. dan Syafrudin. (2007). Model Numerik 2-D (Lateral dan Longitudinal) Sebaran Polutan Cadmium (Cd) di Muara Sungai (Studi Kasus: Muara Sungai Babon, Semarang). Jurnal Presipitasi. Vol 3 pp.1-8.

Brown, LC dan Barnwell, TO. (1987). The Enhanced Stream Water Quality Models Qual2E and Qual2EUNCAS: Documentation and User Manual. Georgia. : U.S. Environmental Protection Agency.

BAPPEDA DIY, (2015). Rancangan Awal Rencana Kerja Pembangunan Daerah (RKPD) Daerah Istimewa Yogyakarta Tahun 2015. Yogyakarta : BAPPEDA DIY

Fatmawati, R., Masrevaniah, A., dan Solichin, M. (2012). Kajian Identifikasi Daya Tampung Beban Pencemaran Kali Ngrowodengan Menggunakan Paket Program Qual2Kw. Jurnal Teknik Pengairan. Vol 3 pp.122-131.

Iskandar, I. (2007). Panduan Pelatihan Pengelolaan Kualitas Air. Jakarta : Puslitbang Sumberdaya Air Kementerian Pekerjaan Umum.(in bahasa Indonesia)

Kannel, PR., Lee, S., Lee,YS., Kanel, SR., dan Pelletier GJ. (2007). Application of Automated Qual2Kw for Water Quality Modeling and Managemenr in The Bagmati River, Nepal. Ecological Modeling. Vol 202 pp.503-517.

Keputusan Menteri Kehutanan Republik Indonesia Nomor SK. 328/Menhut-II/2009 tentang Penetapan Daerah Aliran Sungai (DAS) Prioritas Dalam Rangka Rencana Pembangunan Jangka Menengah (RPJM) Tahun 2010-2014. Jakarta : Kementerian Kehutanan.(in bahasa Indonesia)

Montgomerry, D.C. (1997). Design and Analysis of Experiments. New York : John Wiley and Sons..

Oliveira, B., Bola, J., Quinteiro, P., Nadais, H., dan Arroja, L. (2012). Application of Qual2Kw Model 
as a Tool for Water Quality Management: Certima River as a Case Study. Environmental Monitoring and Assessment. Vol 184 pp.6197-6210.

Park, SS dan Lee, YS. (2002). A Water Quality Modeling Study of TheNakdong River, Korea. Ecological Modeling. Vol 152 pp.65-75

Pelletier, GJ., Chapra, SC., dan Tao H. (2006). Qual2Kw - A Framework for Modeling Water Quality in Streams and Rivers Using a Genetic Algorithm for Calibration. Environmental Modeling\& Software. Vol 21 pp.419-425.

Peraturan Menteri Negara Lingkungan Hidup Nomor 01 Tahun 2010 tentang Pedoman Penerapan Daya Tampung Beban Pencemar pada Sumber Air. Jakarta : Kementerian Lingkungan Hidup.(in bahasa Indonesia)
Soewarno. (2014). Aplikasi Metode Statistika Untuk Analisis Data Hidrologi. Yogyakarta.: Graha Ilmu. (in bahasa Indonesia]

Sudarmadji, Suprayogi S., Widyastuti M., dan Harini R. (2011). Konservasi Mata Air Berbasis Masyakarat di Unit Fisiografi Pengunungan Baturagung, Ledok Wonosari dan Perbukitan Karst Gunung Sewu, Kabupaten Gunungkidul. Jurnal Teknosains. Vol 1 pp.1-69.

Sudarmadji dan Widyastuti M. (2014). Dampak dan Kendala Wisata Waduk Sermo Dari Aspek Lingkungan Hidup dan Risiko Bencana. Jurnal Teknosains. Vol 3 pp.81-166.

Wardhana, W.A. (2001). Dampak Pencemaran Lingkungan. Yogyakarta : Andi Offset(in bahasa Indonesia) 